\title{
Synthesis, Characterization, and Photophysical Properties of Iridium Complexes with an 8-Phenylquinoline Framework. The First Six-Membered Chelated Iridium Complexes for Electroluminance
}

\author{
Hao-Chun Li, Pi-Tai Chou, ${ }^{*}$ Ya-Hui Hu, Yi-Ming Cheng, and Rai-Shung Liu* \\ Department of Chemistry, National Tsing-Hua University, \\ Hsinchu, Taiwan, Republic of China, and Department of Chemistry, National Taiwan \\ University, Taipei, 10617, Taiwan, Republic of China
}

Received October 18, 2004

\begin{abstract}
A series of six-membered chelated iridium complexes bearing an 8-phenylquinoline framework have been prepared and characterized with an X-ray diffraction study. The photophysical properties of these complexes were examined with appropriate spectroscopic methods. The results, in combination with ab initio approaches, led us to clearly assign various electronic transition states. One salient feature for these red complexes is the appearance of a dual strong absorption band around $425-500 \mathrm{~nm}$, which incorporates a state mixing between ${ }^{1} \mathrm{MLCT}$ and $\pi-\pi^{*}$ manifolds. These complexes show deep red phosphorescent emissions $(650-680 \mathrm{~nm})$, with short lifetimes of 1.7-3.0 $\mu$ s and moderate quantum yields of $0.05-0.11$ in deaerated $\mathrm{CH}_{3} \mathrm{CN}$. The electroluminance performance of these species shows a promising perspective in the OLED display. One representative, Ir[8-(3,5-difluorophenyl)quinoline ${ }_{2}$ (acac) (4c), shows a $\eta_{\text {ext }}$ value of $2.04 \%$ at $J=20 \mathrm{~mA} / \mathrm{cm}^{2}$ and the maximum brightness is $3427 \mathrm{~cd} / \mathrm{m}^{2}(x=0.68, y=0.32)$ with a full width at halfmaximum of only $60 \mathrm{~nm}$ at $16 \mathrm{~V}$, demonstrating the first six-membered chelated iridium complexes to suit applications in OLED devices.
\end{abstract}

Cyclometalated iridium complexes have attracted considerable attention in material research because of their outstanding performance in organic light-emitting diodes (OLED).$^{1-4}$ The strong spin-orbit coupling caused by the heavy atom (e.g., $\operatorname{Ir}(\mathrm{III}))$ effect leads to efficient intersystem crossing from the singlet $\left(\mathrm{S}_{1}\right)$ to the triplet $\left(\mathrm{T}_{n}\right)$ as well as the enhancement of the $\mathrm{T}_{1}-\mathrm{S}_{0}$ transition. OLED devices based on these phosphors can significantly improve electroluminance performance because both singlet and triplet excitons can be harvested for light emissions, theoretically attaining $100 \%$ internal quantum efficiencies. Interestingly, all these iridium complexes are prepared in a five-membered chelated

\footnotetext{
* To whom correspondence should be addressed. E-mail: rsliu@mx.nthu.edu.tw.

(1) (a) Baldo, M. A.; O’Brien, D. F.; You, Y.; Shoustikov, A.; Sibley, S.; Thompson, M. E.; Forrest, S. R. Nature 1998, 395, 151. (b) Kohler, A.; Wilson, J. S.; Friend, R. H. Adv. Mater. 2002, 14, 701.

(2) (a) Baldo, M. A.; Thompson, M. E.; Forrest, S. R. Nature 2000 , 403, 750. (b) Pfeiffer, M.; Forrest, S. R.; Leo, K.; Thompson, M. E. Adv. Mater. 2002, 14, 1633. (c) Holmes, R. J.; Forrest, S. R.; Tung, Y.-J.; Kwong, R. C.; Brown, J. J.; Garon, S.; Thompson, M. E. Appl. Phys. Lett. 2003, 82, 2422.

(3) (a) Baldo, M. A.; Lamansky, S.; Burrows, P. E.; Thompson, M. E.; Forrest, S. R. Appl. Phys. Lett. 1999, 75, 4. (b) Adachi, C.; Baldo, M. A.; Thompson, M. E.; Forrest, S. R. Appl. Phys. Lett. 2000, 77, 904. (c) Tamayo, A. B.; Alleyne, B. D.; Djurovich, P. I.; Lamansky, S.; Tsyba, I.; Ho, N. N.; Bau, R.; Thompson, M. E. J. Am. Chem. Soc. 2003, 125, 7377. (d) Adachi, C.; Baldo, M. A.; Forrest, S. R.; Lamansky, S.; Thompson, M. E.; Kwong, R. C. Appl. Phys. Lett. 2001, 78, 1622. (e) Tsuzuki, T.; Shirasawa, N.; Suzuki, T.; Tokito, S. Adv. Mater. 2003 15, 1455. (f) Markham, J. P. J.; Samuel, I. D. W.; Lo, S.-C.; Burn, P. L.; Weiter, M.; Bässler, H. J. Appl. Phys. 2004, 95, 438. (g) Polson, M.; Fracasso, S.; Bertolasi, V.; Ravaglia, M.; Scandola, F. Inorg. Chem. 2004, 43, 1950. (h) Slinker, J. D.; Gorodetsky, A. A.; Lowry, M. S.; Wang, J.-J.; Parker, S.; Rohl, R.; Bernhard, S.; Malliaras, G. G. J. Am. Chem. Soc. 2004, 126, 2763.
}

framework (A) ${ }^{1-6}$ as depicted in Figure 1, and to our best knowledge, no information is known about the

(4) (a) D’Andrade, B. W.; Brooks, J.; Adamovich, V.; Thompson, M. E.; Forrest, S. R. Adv. Mater. 2002, 14, 1032. (b) D'Andrade, W.; Thompson, M. E.; Forrest, S. R. Adv. Mater. 2002, 14, 147. (c) Lamansky, S.; Djurovich, P.; Murphy, D.; Abdel-Razzaq, F.; Lee, H.E.; Adachi, C.; Burrows, P. E.; Forrest, S. R.; Thompson, M. E. J. Am. Chem. Soc. 2001, 123, 4304. (d) Kolosov, D.; Adamovich, V.; Djurovich P.; Thompson, M. E.; Adachi, C. J. Am. Chem. Soc. 2002, 124, 9945. (e) Adachi, C.; Baldo, M. A.; Thompson, M. E.; Forrest, S. R. J. Appl. Phys. 2001, 90, 5048. (f) Adamovich, V.; Brooks, J.; Tamayo, A.; Alexander, A. M.; Djurovich, P. I.; D'Andrade, B. W.; Adachi, C.; Forrest, S. R.; Thompson, M. E. New J. Chem. 2002, 1171. (g) Huang, W.-S.; Lin, J.-T.; Chien, C.-H.; Tao, Y.-T.; Sun, S.-S.; Wen, Y.-S. Chem. Mater. 2004, 16, 2480. (h) Laskar, I. R.; Chen, T.-M. Chem. Mater. 2004, 16, 111.

(5) (a) Xie, H.-Z.; Liu, M.-W.; Wang, O.-Y.; Zhang, X.-H.; Lee, C.-S.; Hung, L.-S.; Lee, S.-T.; Teng, P.-F.; Kwong, H.-L.; Zheng, H.; Che, C.M. Adv. Mater. 2001, 13, 1245. (b) Ikai, M.; Tokito, S.; Sakamoto, Y. Suzuki, T. Appl. Phys. Lett. 2001, 79, 156. (c) Chen, F. C.; Yang, Y. Appl. Phys. Lett. 2002, 80, 2308. (d) Grushin, V. V.; Herron, N.; LeCloux, D. D.; Marshall, W. J.; Petrov, V. A.; Wang, Y. Chem. Commun. 2001, 9, 1494. (e) Tokito, S.; Iijima, T.; Tsuzuki, T.; Sato, F. Appl. Phys. Lett. 2003, 83, 2459. (f) Holmes, R. J.; D’Andrade, B. W.; Forrest, S. R.; Ren, X.; Li, J.; Thompson, M. E. Appl. Phys. Lett. 2003 83, 3818. (g) Tokito, S.; Iijima, T. Suzuri, Y. Kita, H.; Tsuzuki, T. Sato, F. Appl. Phys. Lett. 2003, 83, 569. (h) Chen, X.; Liao, J.-L.; Liang, Y.; Ahmed, M. O.; Tseng, H.-E.; Chen, S.-A. J. Am. Chem. Soc. 2003 125, 636. (i) Niu, Y.-H.; Chen, B.; Liu, S.; Yip, H.; Bardecker, J.; Jen, A. K.-Y.; Kavitha, J.; Chi, Y.; Shu, C.-F.; Tseng, Y.-H.; Chien, C.-H. Appl. Phys. Lett. 2004, 85, 1619.

(6) (a) Okada, S.; Iwawak, H.; Furugori, M.; Kamatani, J.; Igawa, S.; Moriyama, T.; Miuva, S.; Tsuboyama, A.; Takiguchi, T.; Mizutani, H. SID Digest 2002, 1360. (b) Tsuboyama, A.; Iwawaki, H.; Furugori, M.; Mukaide, T.; Kamatani, J.; Igawa, S.; Moriwama, T.; Miura, S.; Takiguchi, T.; Okada, S.; Hoshino, M.; Ueno, K. J. Am. Chem. Soc. 2003, 125, 12971. (c) Su, Y.-J.; Huang, H.-L.; Li, C.-L.; Cheng, C.-H.; Tao, Y.-T.; Chou, P.-T.; Datta, S.; Liu, R.-S. Adv. Mater. 2003, 15, 884. (d) Li, C.-L.; Su, Y.-J.; Tao, Y.-T.; Chou, P.-T.; Chien, C.-H.; Cheng, C.-C.; Liu, R.-S. Adv. Funct. Mater., in press. 


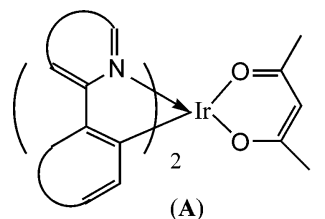

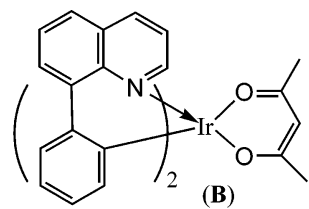

(A) (B)

Figure 1.
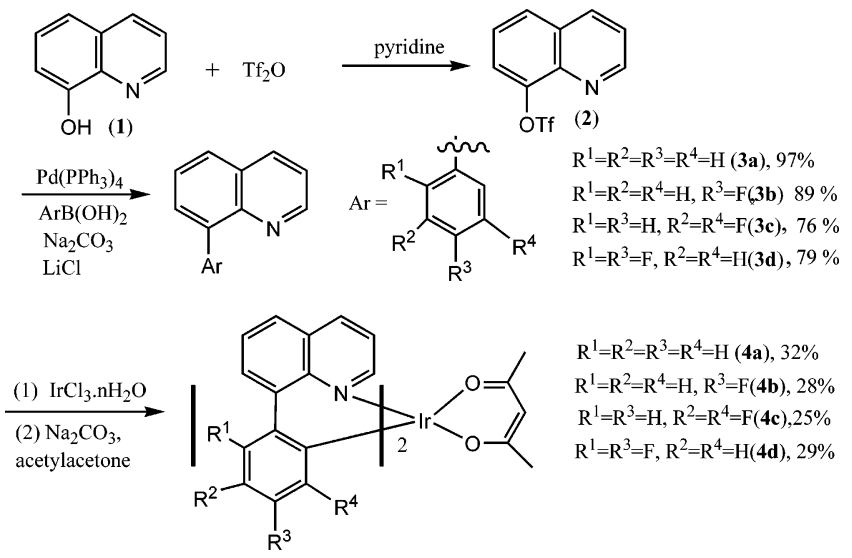

Figure 2.

suitability of six-membered chelated iridium complexes toward application in OLED devices. Herein, we report the preparation, photophysical properties, and the first OLED performances of the iridium complexes chelated with a six-membered 8-phenylquinoline framework $(\mathbf{B})$, depicted in Figure 1.

\section{Results and Discussion}

Figure 2 depicts the synthetic pathway of 8-phenylquinoline required for cyclometalated iridium complexes. 8-Hydroxyquinoline was converted to its triflate derivative 2, which underwent subsequent Suzukicoupling reactions ${ }^{7}$ with a suitable phenyl derivative and gave the desired 8-phenylquinoline derivatives $\mathbf{3 a}-\mathbf{d}$ in satisfactory yields $(76-97 \%)$. These ligands were transformed into cyclometalated iridium complexes $4 \mathbf{a}-\mathbf{d}$ via heating with $\mathrm{IrCl}_{3} \cdot n \mathrm{H}_{2} \mathrm{O}$ in ethoxyethanol, followed by treatment of the resulting diiridium precursors ${ }^{4 \mathrm{c}}$ with a mixture of acetyl acetone $/ \mathrm{Na}_{2} \mathrm{CO}_{3}$; the overall yields were $25-32 \%$.

The molecular structure of representative compound 3b has been characterized by an X-ray diffraction study, ${ }^{8}$ with the ORTEP drawing and selected bond distances and angles shown in Figure 3. The coordination geometry around iridium approximates an octahedral geometry, with two nitrogen ligating atoms trans to each other, whereas the two acetylacetonate oxygen atoms lie trans to the ligating carbon atoms of 8-phenylquinoline. The molecular structure of $\mathbf{4} \mathbf{b}$ has near $C_{2^{-}}$ symmetry, which accounts for an equivalent pattern in the proton NMR peaks of the two chelated ligands. Notably, the six-membered chelated iridium geometry is not coplanar and is close to a twisted boat form. A dihedral angle of $28.9^{\circ}$ is formed between the planes

(7) (a) Echavarren, A. M.; Stille, J. K. J. Am. Chem. Soc. 1987, 109, 5478. (b) Huth, A.; Beetz, I.; Schumann, I. Tetrahedron 1989, 21, 6679.

(8) Crystallographic data for compound 4b: $a=11.4624(9) \AA, b=$ $11.8852(9) \AA, c=12.1307(9) \AA, \alpha=101.170(2)^{\circ}, \beta=11.4624(9)^{\circ}, \gamma=$ $11.4624(9)^{\circ}, V=1514.7(2) \AA^{3}, Z=2$. Of the 17909 unique reflections, 7486 were considered observed having $I>2 \sigma(I)$. Final $R=0.0331$ and $R_{\mathrm{w}}=0.1156$.

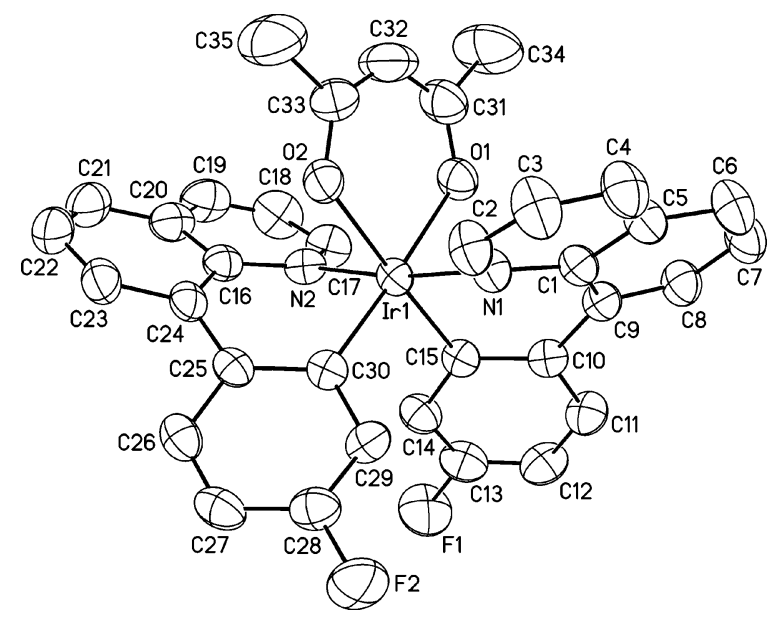

Figure 3. ORTEP diagram of $\mathbf{4 b}$. Selected bond distances $(\AA)$ and angles $(\mathrm{deg}): \operatorname{Ir}(1)-\mathrm{N}(1)=2.025(4), \operatorname{Ir}(1)-\mathrm{N}(2)=$ 2.048(5), $\operatorname{Ir}(1)-\mathrm{O}(1)=2.128(4), \operatorname{Ir}(1)-\mathrm{O}(2)=2.136(4), \mathrm{Ir}-$ $(1)-\mathrm{C}(15)=1.995(5), \operatorname{Ir}(1)-\mathrm{C}(30)=1.984(5), \mathrm{C}(30)-\operatorname{Ir}(1)-$ $\mathrm{C}(15)=92.8(2), \mathrm{C}(30)-\operatorname{Ir}(1)-\mathrm{N}(1)=94.84(19), \mathrm{C}(15)-$ $\operatorname{Ir}(1)-\mathrm{N}(1)=90.37(19), \mathrm{C}(30)-\operatorname{Ir}(1)-\mathrm{N}(2)=90.40(19)$, $\mathrm{C}(15)-\operatorname{Ir}(1)-\mathrm{N}(2)=94.70(19), \mathrm{C}(15)-\operatorname{Ir}(1)-\mathrm{O}(1)=89.56-$ (18), $\mathrm{N}(1)-\operatorname{Ir}(1)-\mathrm{O}(1)=86.79(17), \mathrm{N}(2)-\operatorname{Ir}(1)-\mathrm{O}(1)=$ 87.75(17), $\mathrm{C}(30)-\operatorname{Ir}(1)-\mathrm{O}(2)=88.45(18), \mathrm{N}(1)-\operatorname{Ir}(1)-\mathrm{O}(2)$ $=87.81(16), \mathrm{N}(2)-\operatorname{Ir}(1)-\mathrm{O}(2)=87.00(17), \mathrm{O}(1)-\operatorname{Ir}(1)-\mathrm{O}(2)$ $=89.22(16)$.

Table 1. Photophysical Data of Iridium Complexes $\mathbf{4 a}-\mathbf{d}$

\begin{tabular}{lllll}
\hline & \multicolumn{1}{c}{$\mathbf{4 a}$} & \multicolumn{1}{c}{$\mathbf{4 b}$} & \multicolumn{1}{c}{$\mathbf{4 c}$} & \multicolumn{1}{c}{$\mathbf{4 d}$} \\
\hline absorption & $448(12760)^{a}$ & $436(13109)$ & $432(14286)$ & $426(9553)$ \\
$\quad(\mathrm{nm})$ & $504(7818)$ & $487(10000)$ & $487(7848)$ & $477(7480)$ \\
PL $\lambda_{\max }$ & $680(670)$ & $666(661)$ & $656(650)$ & $650(647)$ \\
$\quad(\mathrm{nm})^{b}$ & & & & \\
$\Phi_{\text {degassed }}$ & 0.05 & 0.07 & 0.09 & 0.11 \\
$\Phi_{\text {aerated }}$ & 0.006 & 0.008 & 0.008 & 0.01 \\
$\tau_{\text {degassed }}$ & 1769 & 2825 & 3072 & 2763 \\
$\quad(\mathrm{~ns})$ & & & & \\
$\tau_{\text {aerated }}(\mathrm{ns})$ & 233 & 292 & 399 & 422 \\
$\tau_{\text {solid }}(\mathrm{ns})$ & 340 & 1073 & 368 & 340 \\
$E_{1 / 2}{ }^{\text {ox }}(\mathrm{V})^{c}$ & 0.85 & 1.00 & 1.03 & 1.02
\end{tabular}

${ }^{a}$ These values in parentheses represent extinction coefficients in $\mathrm{M}^{-1} \mathrm{~cm}^{-1} .{ }^{b}$ Data are obtained in degassed acetonitrile, and data in parenthesis show the property in solid state. ${ }^{c}$ The values are calculated relative to $\mathrm{Cp}_{2} \mathrm{Fe} / \mathrm{Cp}_{2} \mathrm{Fe}^{+}$vs NHE in $\mathrm{CH}_{2} \mathrm{Cl}_{2}$ solution.

defined by $\mathrm{C} 24-\mathrm{C} 16-\mathrm{N} 2$ and $\mathrm{C} 25-\mathrm{C} 30-\mathrm{Ir}$. Although this nonplanar structure is expected to weaken the iridium-ligand bonding, it is not reflected in the Ir-C and $\mathrm{Ir}-\mathrm{N}$ distances of complex $\mathbf{4 b}$. In comparison to those of the five-membered chelated $f a c-\operatorname{Ir}(\mathrm{ppy})_{3},{ }^{9}$ the $\operatorname{Ir} 1-\mathrm{C} 30(1.984 \AA)$ and $\operatorname{Ir} 1-\mathrm{C} 15(1.995 \AA)$ bonds of complex $4 \mathrm{~b}$ are similar to those $(2.003 \AA)$ for $\mathrm{fac}-\operatorname{Ir}(\mathrm{ppy})_{3}$, whereas the $\operatorname{Ir} 1-\mathrm{N}$ bonds $(2.025$ and $2.048 \AA$ ) are significantly shorter than those $\left(2.135 \AA\right.$ ) of $f a c-\operatorname{Ir}(\mathrm{ppy})_{3}$.

Table 1 and Figure 4 show the photophysical properties of iridium complexes $\mathbf{4 a}-\mathbf{d}$. By comparison to free 8-phenylquinoline ligands $\mathbf{3 a}-\mathbf{d}$, the absorption spectral features around $330-350 \mathrm{~nm}$ in Figure 4 are reasonably assigned to the ${ }^{1} \pi-\pi^{*}$ transition of the quinoline chromophore. The most salient feature for these red complexes is the appearance of two strong absorption bands

(9) (a) Lamansky, S.; Djurovich, P.; Murphy, D.; Abdel-Razzaq, F.; Kwong, R.; Tsyba, I.; Bortz, M.; Mui, B.; Bau, R.; Thompson, M. E. Inorg. Chem. 2001, 40, 1704. (b) Colombo, M. G.; Brunold, T. C.; Riedener, T.; Güdel, H. U.; Förtsch, M.; Znorg, B. Inorg. Chem. 1994, $33,545-550$. 


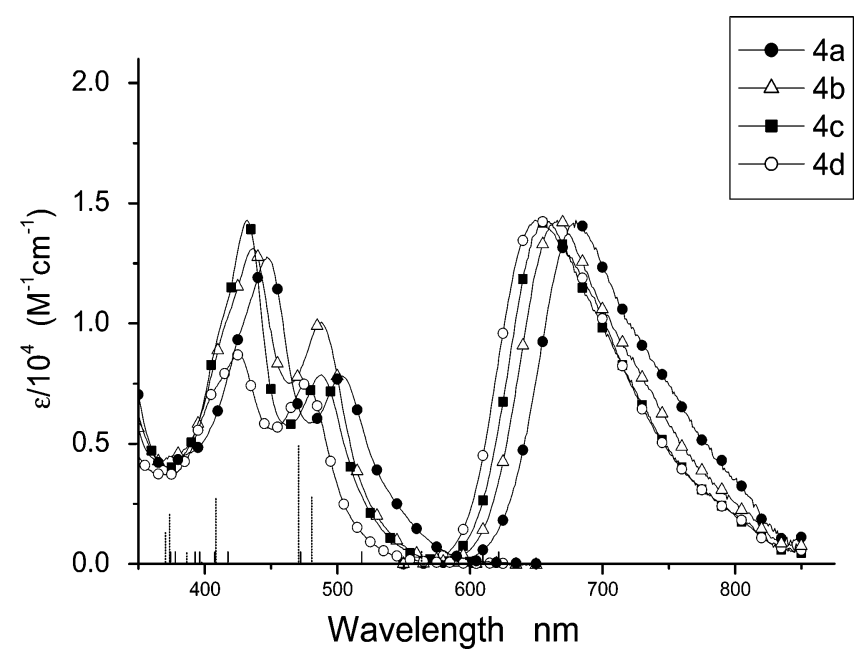

Figure 4. UV-vis absorption and emission spectra of complexes $4 \mathbf{a}-\mathbf{d}$. The line sign shown on the wavelength coordinate indicates the calculated energy level of various transitions in $\mathbf{4 b}$, in which the dashed and solid line denote singlet and triplet excited states, respectively. See text for a detailed elaboration of the ab initio approach.

in the region of $420-500 \mathrm{~nm}$ with peak wavelengths at $425-450 \mathrm{~nm}\left(\epsilon=9553-14286 \mathrm{M}^{-1} \mathrm{~cm}^{-1}\right)$ and $475-$ $500 \mathrm{~nm}\left(\epsilon=7000-14000 \mathrm{M}^{-1} \mathrm{~cm}^{-1}\right)$, which are apparently absent in the free neutral 8-phenylquinoline ligands.

To obtain a clear assignment of these absorption features, we have carried out a reliable ab initio approach for $\mathbf{4 b}$ using the B3LYP density functional theory, in which double- $\zeta$ quality basis sets were employed for the Ir atom. In addition, a relativistic effective core potential on Ir replaced the inner core electrons, leaving the outer core $\left[(5 s)^{2}(5 p)^{6}\right]$ electrons and the $(5 \mathrm{~d})^{6}$ valence electrons of Ir ${ }^{\mathrm{III}}$. The ground state geometry was adapted from the truncated X-ray data of $\mathbf{4 b}$ without further optimization. A time-dependent DFT (TDDFT) calculation using the B3LYP functional was then performed to estimate the corresponding energy of transition (for details, see the Experimental Section). The calculated parameters for various lowerlying transitions together with the associated frontier orbitals are listed in Table 2. For a fair comparison, the calculated energy levels are also depicted in Figure 4. On the basis of Figure 4 and Table 2, it is reasonable to assign the two major bands at 420-450 and 475-500 $\mathrm{nm}$ to $\mathrm{S}_{2}$ and $\mathrm{S}_{3}$ states, respectively, both of which incorporate mainly a spin-allowed metal-ligand (cyclometalated 8-phenylquinoline) charge transfer ( $\left.{ }^{1} \mathrm{MLCT}\right)$ and, in part, a $\pi-\pi^{*}$ intraligand transition from phenyl to cyclometalated 8-phenylquinoline (see Table 1). Note that the much broader absorption spectral feature in solution, in reality, is due to the vibronic coupling that is omitted in the ab initio approach. The lowest singlet state, i.e., the $\mathrm{S}_{1}$, was calculated to be at $\sim 563 \mathrm{~nm}$, which is obscured in the absorption spectra due to the overlap with the much stronger $\mathrm{S}_{2}$ band. The frontier orbital (HOMO $\rightarrow$ LUMO) analysis of the $\mathrm{S}_{1}$ also indicates a state mixing between ${ }^{1} \mathrm{MLCT}$ and $\Pi-\Pi^{*}$ manifolds. Moreover, the lowest triplet state originates from HOMO $-1 \rightarrow$ LUMO $(+91 \%)$ and HOMO $\rightarrow$ LU$\mathrm{MO}+1$ (9\%, see Table 1), which apparently possess a mixed ${ }^{3} \mathrm{MLCT}$ and intraligand $\pi$ (phenyl) $-\pi^{*}(8$-phen- ylquinoline) character. The $\mathrm{S}_{0} \rightarrow \mathrm{T}_{1}$ transition is estimated to be at $\sim 621 \mathrm{~nm}$, which is consistent with the phosphorescence peak wavelength at $666 \mathrm{~nm}$, taking into account the bathochromic shift of the emission due to the solvent stabilization.

In the PL spectra, the parent 4a shows a single, deepred emission band with a wavelength up to $680 \mathrm{~nm}$ in $\mathrm{CH}_{3} \mathrm{CN}$. Intriguingly, by comparison, its five-membered chelated 2-phenylquinoline isomer is known to be an orange emitter $(\lambda=580 \mathrm{~nm}){ }^{4 \mathrm{c}}$ As shown in Table 1, the emission is drastically quenched with oxygen. The excited state lifetimes of complexes $4 \mathbf{a}-\mathbf{d}$ were measured to be $0.23-0.42 \mu \mathrm{s}$ in aerated $\mathrm{CH}_{3} \mathrm{CN}$, but increased to $1.77-3.07 \mu \mathrm{s}$ in deaerated $\mathrm{CH}_{3} \mathrm{CN}$. Similarly, the quantum yields in the emissions were only $0.006-0.010$ in aerated $\mathrm{CH}_{3} \mathrm{CN}$, but increased to $0.05-$ 0.11 in deaerated $\mathrm{CH}_{3} \mathrm{CN}$. The nearly diffusion-controlled oxygen quenching rate in $\mathrm{CH}_{3} \mathrm{CN}$ leads to the unambiguous assignment to a phosphorescent emission.

The presence of a fluoro substituent in the phenyl group leads to a fine-tuning of the emission gap. In comparison the parents $\mathbf{4 a}$ and $\mathbf{4 b}$, bearing one fluoro substituent, exhibit a nearly $10 \mathrm{~nm}$ hypsochromic shift in the emission peak wavelength. Moreover, 4d, with dual fluoro substituents at resonant ortho- and parapositions relative to 8-phenylquinoline, reveals a shorter peak wavelength $(656 \mathrm{~nm})$ than that $(650 \mathrm{~nm})$ for $\mathbf{4 c}$, bearing fluoro substituents at the nonresonant metaposition. The results, in combination with a large Stokes shift of $>150 \mathrm{~nm},{ }^{10,11}$ render further support for the intraligand $\pi$ (phenyl) $-\pi^{*}$ (8-phenylquinoline) character, in part, predicted from the theoretical approach (vide supra). However, the spectral shift is considered to be small, indicating that ${ }^{3} \mathrm{MLCT}\left(\mathrm{d}-\pi^{*}\right.$ (8-phenylquinoline)), as predicted by the theoretical approach, should be incorporated in the $\mathrm{T}_{1}$ manifold.

In brief, the information provided above concludes that the six-membered chelated complexes $4 \mathbf{a}-\mathbf{d}$ are equally active in generating the phosphorescent emission via a strong spin-orbit coupling, with phosphorescence lifetimes comparable to those of five-membered iridium phosphors. The relatively low quantum yields of complexes $4 \mathbf{a}-\mathbf{d}$ may be caused by two mechanisms: 12 (1) the low energy gap $(650-680 \mathrm{~nm})$, the relaxation of which is often accompanied with a nonradiative process, and (2) the nonrigid nature of the six-membered chelated structures, in which the nonradiative deactivation may be associated with the large-amplitude skeletal motion.

We also examined the electrochemistry of complexes $\mathbf{4 a}-\mathbf{d}$ via cyclic voltammetry using ferrocene as the internal standard. These complexes display reversible couples in anodic oxidation within the conditions -1.60 $<E<+1.80 \mathrm{~V}$. The fluoro substituents $\mathbf{4 b}-\mathbf{d}$ shift the potentials $[+(0.99-1.22 \mathrm{~V})]$ to a more positive (anodic) potential when compared to the parent complex $4 \mathbf{a}$ $(+0.88 \mathrm{~V})$. This phenomenon is consistent with the expectation that the fluoro groups of complexes $\mathbf{4 b}-\mathbf{d}$ decrease their HOMO energy levels (vide infra). We

(10) Colombo, M. G.; Hauser, A.; Güdel, H. U. Inorg. Chem. 1993, $32,3088$.

(11) Schimid, B.; Garces, F. O.; Watts, R. J. Inorg. Chem. 1994, 33,

(12) (a) Caspar, J. V.; Meyer, T. J. J. Phys. Chem. 1983, 87, 952. (b) Cummings, S. D.; Eisenberg, R. J. J. Am. Chem. Soc. 1996, 118, 1949. 
Table 2. Calculated Singlet and Triplet Transitions and the Corresponding Frontier Orbitals for Complex 4b

(1)

\begin{tabular}{|c|c|c|c|c|}
\hline state & excitation & $E_{\text {cal }}(\mathrm{eV})$ & $\lambda_{\text {cal }}(\mathrm{nm})$ & $(f)$ \\
\hline \multicolumn{5}{|c|}{ Singlet Excited States } \\
\hline 1 & HOMO $\rightarrow$ LUMO $(+96 \%)$ & 2.20 & 563 & 0.0020 \\
\hline 2 & $\mathrm{HOMO} \rightarrow \mathrm{LUMO}+1(+64 \%), \mathrm{HOMO}-1 \rightarrow \mathrm{LUMO}(+28 \%)$ & 2.58 & 480 & 0.0121 \\
\hline 3 & HOMO-1 $\rightarrow$ LUMO $(+59 \%)$, HOMO $\rightarrow$ LUMO+1 (27\%) & 2.63 & 471 & 0.0227 \\
\hline 4 & $\mathrm{HOMO}-1 \rightarrow \mathrm{LUMO}+1(+82 \%)$ & 3.04 & 408 & 0.0126 \\
\hline \multicolumn{5}{|c|}{ Triplet Excited States } \\
\hline 1 & HOMO $-1 \rightarrow$ LUMO $(+91 \%)$, HOMO $\rightarrow$ LUMO+1 $(9 \%)$ & 1.99 & 622 & \\
\hline 2 & $\mathrm{HOMO} \rightarrow \mathrm{LUMO}(+82 \%), \mathrm{HOMO}-1 \rightarrow \mathrm{LUMO}+1(10 \%), \mathrm{HOMO} \rightarrow \mathrm{LUMO}+1(+8 \%)$ & 2.03 & 610 & \\
\hline
\end{tabular}

further measured the HOMO and LUMO energy levels of representative compounds $4 \mathbf{a}$ and $\mathbf{4 c}$ to ascertain the role of fluoro substitution. The HOMO levels for species $4 \mathbf{a}$ and $4 \mathbf{c}$, according to the photoelectron spectroscopy, were -5.25 and $-5.42 \mathrm{eV}$, respectively. On the basis of their UV absorption spectroscopy, the LUMO levels of $4 \mathbf{a}$ and $4 \mathbf{c}$ are thus calculated to be -3.06 and -2.97 $\mathrm{eV}$, respectively. Compared to parent compound $4 \mathbf{a}$, the 2,4-difluorophenyl substitution in $\mathbf{4 c}$ leads to a larger decrease in energy for the HOMO than the LUMO orbitals, consistent with the results obtained from both emission spectroscopy and theoretical approaches.

OLEDs using these iridium complexes were fabricated by high-vacuum $\left(5 \times 10^{-6}\right.$ Torr $)$ thermal evaporation onto precleaned glass substrates. The devices were prepared $^{6 c}$ from ITO/NPB $(40 \mathrm{~nm}) / \mathbf{4 b}(6 \%)$ in $\mathrm{CBP}(30$ $\mathrm{nm}) / \mathrm{BCP}(10 \mathrm{~nm}) / \mathrm{Alq}(30 \mathrm{~nm}) / \mathrm{Mg}: \mathrm{Ag}$, in which CBP acts as a hole material, bathocuproine (BCP) as a hole blocker, and 4,4'-bis[N-(naphthyl)- $N$-phenylamino]biphenyl (NPB) and tris(8-hydroxyquinoline)aluminum $\left(\mathrm{Alq}_{3}\right)$ as a hole-transport and electron-transport material, respectively. The electroluminance spectra and corresponding data of complexes $\mathbf{4 a}-\mathbf{d}$ are summarized in Table 3. All four devices exhibited deep red emissions in the $634-650 \mathrm{~nm}$ region, which are independent of the applied voltage of 6-18 V. No emission bands due to $\mathrm{CBP}, \mathrm{NPB}$, or $\mathrm{Alq}_{3}$ were observed in the electrolu-
Table 3. Electrophosphorescence Data for Iridium Complexes $4 \mathbf{a}-\mathbf{d}^{a}$

\begin{tabular}{cccccrc}
\hline complex & $\begin{array}{c}\text { brightness } \\
\left(\mathrm{cd} / \mathrm{m}^{2}\right)\end{array}$ & $\begin{array}{c}\mathrm{EQE} \\
(\%)\end{array}$ & $\begin{array}{c}\mathrm{PE} \\
(\mathrm{cd} / \mathrm{A})\end{array}$ & $\begin{array}{c}\mathrm{LE} \\
(\mathrm{lm} / \mathrm{W})\end{array}$ & $\begin{array}{c}\text { voltage } \\
(\mathrm{V})\end{array}$ & $\begin{array}{c}\text { CIE } \\
\text { coordinate }\end{array}$ \\
\hline $\mathbf{4 a}$ & $115^{b}$ & 1.89 & 0.58 & 0.26 & 6.89 & $\mathrm{X}=0.70$ \\
& $446^{c}$ & 1.46 & 0.45 & 0.15 & 9.70 & $\mathrm{Y}=0.30$ \\
4 & $1102^{d}$ & 0.88 & 0.27 & 0.05 & 15.82 & $(668 \mathrm{~nm})^{e}$ \\
$4 \mathbf{b}$ & 213 & 1.93 & 1.07 & 0.47 & 7.11 & $\mathrm{X}=0.69$ \\
& 747 & 1.38 & 0.75 & 0.24 & 9.70 & $\mathrm{Y}=0.31$ \\
$4 \mathbf{c}$ & 1668 & 0.76 & 0.42 & 0.11 & 15.22 & $(650 \mathrm{~nm})$ \\
& 340 & 2.04 & 1.70 & 0.60 & 8.92 & $\mathrm{X}=0.68$ \\
4 & 1333 & 1.60 & 1.33 & 0.37 & 11.27 & $\mathrm{Y}=0.32$ \\
$4 \mathbf{4}$ & 3102 & 0.93 & 0.77 & 0.17 & 14.43 & $(638 \mathrm{~nm})$ \\
& 448 & 2.42 & 2.24 & 0.83 & 8.20 & $\mathrm{X}=0.68$ \\
& 1604 & 1.73 & 1.60 & 0.45 & 10.59 & $\mathrm{Y}=0.32$ \\
& 3415 & 0.93 & 0.86 & 0.18 & 14.66 & $(634 \mathrm{~nm})$
\end{tabular}

${ }^{a}$ For each parameter, the data in different rows correspond to those measured at different current densities. ${ }^{b} J=20 \mathrm{~mA} / \mathrm{cm}^{2}$. ${ }^{c} J=100 \mathrm{~mA} / \mathrm{cm}^{2} .{ }^{d} J=400 \mathrm{~mA} / \mathrm{cm}^{2} .{ }^{e}$ The values in parentheses represent the maximum EL emission.

minance (EL) spectra. The corresponding CIE coordinates are $x=0.70, y=0.30$ for $4 \mathbf{a}, x=0.69, y=0.31$ for $\mathbf{4 b}, x=0.68, y=0.32$ for $4 \mathbf{c}$, and $x=0.68, y=0.32$ for $4 d$.

The corresponding EL emission peak wavelengths of $\mathbf{4 a}-\mathbf{d}$ were observed at $668,650,638$, and $634 \mathrm{~nm}$, being in good correlation with the tendency of the hypsochromic shift in solution phase. Among these four phosphors, $\mathbf{4 c}$ and $\mathbf{4 d}$ show better EL performance than $\mathbf{4 a}$ and $\mathbf{4 b}$ 
in view of maximum brightness and external quantum efficiency. The better EL performance of complexes 4c and $\mathbf{4 d}$ can be attributed to their hypsochromic shifts of the emission maximum, in which the relatively larger energy gaps are less perturbed by nonradiative processes. Using complex 4c, a maximum brightness of $3427 \mathrm{~cd} / \mathrm{m}^{2}$ was obtained at $16 \mathrm{~V}$. The external quantum efficiency $\eta_{\text {ext }}$ of this complex was 2.04 at $J=20 \mathrm{~mA} /$ $\mathrm{cm}^{2}$, where luminance efficiency and power efficiency were $1.70 \mathrm{~cd} / \mathrm{A}$ and $0.60 \mathrm{~lm} / \mathrm{W}$, respectively. The $\eta_{\text {ext }}$ value dropped slowly to 0.93 at $J=400 \mathrm{~mA} / \mathrm{cm}^{2}$, where luminance efficiency and power efficiency were $0.77 \mathrm{~cd} / \mathrm{A}$ and $0.17 \mathrm{~lm} / \mathrm{W}$, respectively. This information reveals that the short phosphorescent lifetime $\tau=3.07 \mu$ s of complex 4c reduces the saturation of the emission site ( $\mathrm{T}-\mathrm{T}$ annihilation). These parameters reflect the promising feature of these six-membered iridium complexes in OLED devices.

\section{Conclusions}

In summary, we have prepared the first iridium complexes with a six-membered chelated structure. Similar to the reported five-membered chelated compounds, these species show strong low-lying absorption bands with a mixed ${ }^{3} \mathrm{MLCT} /{ }^{3} \pi-\pi^{*}$ character, indicating an unusually strong spin-orbit coupling due to the heavy atom (Ir) effect and, perhaps, the short, sixmembered coordinating distance. These complexes show deep red phosphorescent emissions $(650-680 \mathrm{~nm})$ with short excited lifetimes of $1.7-3.0 \mu \mathrm{s}$ and moderate quantum yields of $0.05-0.11$ in deaerated $\mathrm{CH}_{3} \mathrm{CN}$. The decent electroluminescent performance of these species demonstrates their promising feature in OLED displays.

\section{Experimental Section}

Syntheses. 8-Quinolyl trifluoromethanesulfonate (2). To a pyridine solution of 8-hydroquinoline ( $4.00 \mathrm{~g}, 27.6 \mathrm{mmol})$ was slowly added trifluoromethanesulfonic anhydride $(9.32 \mathrm{~g}$, $33.1 \mathrm{mmol}$ ) at $0{ }^{\circ} \mathrm{C}$. The resulting mixture was stirred at $0{ }^{\circ} \mathrm{C}$ for $5 \mathrm{~min}$ and warmed to $23{ }^{\circ} \mathrm{C}$ with stirring for $25 \mathrm{~h}$. The resulting mixture was poured into water and extracted with ethyl acetate. The ethyl acetate extract was washed sequentially with water, $10 \%$ aqueous hydrochloric acid solution, and water, dried over $\mathrm{MgSO}_{4}$, and concentrated to yield an oil. Chromatography (hexanes/EtOAc, 10:1, $R_{f}=0.40$ ) afforded 8-quinolyl trifluoromethanesulfonate (2) as a colorless oil, which solidified on standing $(6.88 \mathrm{~g}, 90 \%)$. IR (Nujol): 2960 $(\mathrm{m}), 2921(\mathrm{~m}), 2865(\mathrm{~m}), 2852(\mathrm{~m}), 1576(\mathrm{~s}), 1541(\mathrm{~s}), 1398(\mathrm{~s})$, 1351(s), 1186(s). ${ }^{1} \mathrm{H} \mathrm{NMR}\left(\mathrm{CDCl}_{3}, 600 \mathrm{M} \mathrm{Hz}\right): \delta 8.97$ (dd, $J=$ $4.2,1.6 \mathrm{~Hz}, 1 \mathrm{H}), 8.13(\mathrm{dd}, J=8.2,1.6 \mathrm{~Hz}, 1 \mathrm{H}), 7.77(\mathrm{dd}, J=$ $8.2,1.1 \mathrm{~Hz}, 1 \mathrm{H}), 7.57(\mathrm{~d}, J=8.2 \mathrm{~Hz}, 1 \mathrm{H}), 7.49(\mathrm{t}, J=8.1 \mathrm{~Hz}$, $1 \mathrm{H}), 7.44(\mathrm{dd}, J=8.3,4.2 \mathrm{~Hz}, 1 \mathrm{H}) .{ }^{13} \mathrm{C} \mathrm{NMR}\left(\mathrm{CDCl}_{3}, 150\right.$ $\mathrm{MHz}): \delta 151.4\left(\mathrm{~d}, J_{\mathrm{CF}}=25.8 \mathrm{~Hz}\right), 145.9,140.8,135.7,129.6$, 128.2 , 125.8, 122.5, 120.9, 118.9 (q, $\left.J_{\mathrm{CF}}=318.6 \mathrm{~Hz}\right)$. HRMS $(70 \mathrm{eV})$ : calcd for $\mathrm{C}_{10} \mathrm{H}_{6} \mathrm{~F}_{3} \mathrm{NO}_{3} \mathrm{~S} 277.0020$, found 277.0026 . Anal. Calcd for $\mathrm{C}_{10} \mathrm{H}_{6} \mathrm{~F}_{3} \mathrm{NO}_{3} \mathrm{~S}$ : C, 43.33; H, 2.18; N, 5.05. Found: C, 43.25; H, 2.19; N, 5.08.

8-(Phenyl)quinoline (3a). To a toluene $(30 \mathrm{~mL})$ solution of 8-quinolyl trifluoromethanesulfonate (2) $(2.26 \mathrm{~g}, 8.15 \mathrm{mmol})$ were added benzyl boronic acid (1.04 g, $8.55 \mathrm{mmol}), \mathrm{LiCl}(1.04$ $\mathrm{g}, 24.4 \mathrm{mmol}), \mathrm{Pd}\left(\mathrm{PPh}_{3}\right)_{4}(0.47 \mathrm{~g}, 0.41 \mathrm{mmol})$, and $\mathrm{Na}_{2} \mathrm{CO}_{3}(2.0$ $\mathrm{M}, 5.3 \mathrm{~mL}$ ) under $\mathrm{N}_{2}$, and the resulting suspension was heated to reflux for $12 \mathrm{~h}$. The mixture was extracted with ethyl acetate, washed with aqueous $\mathrm{NaCl}$ solution, dried with $\mathrm{MgSO}_{4}$, and concentrated to yield a brownish solid. Chroma- tography (hexanes/EtOAc, 20: $1, R_{f}=0.50$ ) afforded 8-phenylquinoline (3a) as a colorless oil, which solidified on standing (1.62 g, 97\%). IR (Nujol): 2960(m), 2921(m), 2865(m), 2852(m), 1576(s), 1541(s), 1398(s), 1351(s). ${ }^{1} \mathrm{H} \mathrm{NMR}\left(\mathrm{CDCl}_{3}, 400\right.$ $\mathrm{MHz}): \delta 8.95(\mathrm{~d}, J=4.2 \mathrm{~Hz}, 1 \mathrm{H}), 8.19(\mathrm{~d}, J=8.2 \mathrm{~Hz}, 1 \mathrm{H})$, $7.81(\mathrm{~d}, J=8.0 \mathrm{~Hz}, 1 \mathrm{H}), 7.74-7.69(\mathrm{~m}, 2 \mathrm{H}), 7.59(\mathrm{t}, J=8.4$ $\mathrm{Hz}, 1 \mathrm{H}), 7.50(\mathrm{t}, J=8.0 \mathrm{~Hz}, 1 \mathrm{H}), 7.43-7.39(\mathrm{~m}, 4 \mathrm{H}) .{ }^{13} \mathrm{C} \mathrm{NMR}$ $\left(\mathrm{CDCl}_{3}, 100 \mathrm{MHz}\right)$ : $\delta 150.2,146.0,140.9,139.5,136.2,130.6$, $130.3,128.7,127.9,127.5,127.3,126.2,120.9$. HRMS (70 eV) calcd for $\mathrm{C}_{15} \mathrm{H}_{11} \mathrm{~N}$ 205.0891, found 205.0887. Anal. Calcd for $\mathrm{C}_{15} \mathrm{H}_{11} \mathrm{~N}$ : C, 87.77; H, 5.40; N, 6.82. Found: C, 87.77; H, 5.39; $\mathrm{N}, 6.83$.

8-(4-Fluorophenyl)quinoline (3b). This compound was prepared from 8-quinolyl trifluoromethanesulfonate (2) and 4-flourobenzylboronic acid according to the procedure described for 8-phenylquinoline (3a). IR (Nujol): 2960(m), 2921(m), 2865(m), 2852(m), 1576(s), 1541(s), 1398(s), 1351(s), 1176(s). ${ }^{1} \mathrm{H}$ $\mathrm{NMR}\left(\mathrm{CDCl}_{3}, 600 \mathrm{MHz}\right): \delta 8.95(\mathrm{dd}, J=6.0,1.8 \mathrm{~Hz}, 1 \mathrm{H}), 8.21$ (dd, $J=8.4,1.8 \mathrm{~Hz}, 1 \mathrm{H}), 7.82(\mathrm{dd}, J=8.1,1.2 \mathrm{~Hz}, 1 \mathrm{H}), 7.69$ $(\mathrm{d}, J=7.2 \mathrm{~Hz}, 1 \mathrm{H}), 7.67-7.64(\mathrm{~m}, 2 \mathrm{H}), 7.59(\mathrm{t}, J=7.8 \mathrm{~Hz}$, $1 \mathrm{H}), 7.41(\mathrm{dd}, J=8.4,4.2 \mathrm{~Hz}, 1 \mathrm{H}) .{ }^{13} \mathrm{C} \mathrm{NMR}\left(\mathrm{CDCl}_{3}, 150\right.$ $\mathrm{MHz}): \delta 162.4\left(\mathrm{~d}, J_{\mathrm{CF}}=244.8 \mathrm{~Hz}\right), 150.2,145.7,139.7,136.6$, $135.2,132.1\left(\mathrm{~d}, J_{\mathrm{CF}}=7.7 \mathrm{~Hz}\right), 130.3,128.8,127.7,126.3,121.1$, $115.0\left(\mathrm{~d}, J_{\mathrm{CF}}=21.2 \mathrm{~Hz}\right)$. HRMS $(70 \mathrm{eV})$ calcd for $\mathrm{C}_{15} \mathrm{H}_{10} \mathrm{FN}$ 223.0797, found 223.0802. Anal. Calcd for $\mathrm{C}_{15} \mathrm{H}_{10} \mathrm{FN}$ : C, 80.70; H, 4.51; N, 6.27. Found: C, 80.73; H, 4.50; N, 6.22.

8-(3,5-Difluorophenyl)quinoline (3c). This compound was similarly prepared from 8-quinolyl trifluoromethanesulfonate (2) and 4,5-diflourophenylboronic acid according to the procedure described for 8-phenylquinoline (3a). IR (Nujol): 2962(m), 2920(m), 2861(m), 2854(m), 1573(s), 1540(s), 1394(s), 1350(s), 1183(s). ${ }^{1} \mathrm{H} \mathrm{NMR}\left(\mathrm{CDCl}_{3}, 600 \mathrm{MHz}\right): \delta 8.95$ $(\mathrm{dd}, J=4.1,1.8 \mathrm{~Hz}, 1 \mathrm{H}), 8.19(\mathrm{~d}, J=8.4,1 \mathrm{H}), 7.85(\mathrm{~d}, J=8.2$ $\mathrm{Hz}, 1 \mathrm{H}), 7.69$ (dd, $J=7.1,1.1 \mathrm{~Hz}, 1 \mathrm{H}), 7.58(\mathrm{t}, J=7.6 \mathrm{~Hz}$, $1 \mathrm{H}), 7.42(\mathrm{dd}, J=8.3,4.2 \mathrm{~Hz}, 1 \mathrm{H}), 7.26-7.22(\mathrm{~m}, 2 \mathrm{H}), 6.85$ $(\mathrm{tt}, J=9.0,2.4 \mathrm{~Hz}, 1 \mathrm{H}) \cdot{ }^{13} \mathrm{C} \mathrm{NMR}\left(\mathrm{CDCl}_{3}, 150 \mathrm{MHz}\right): \delta 162.5$ $\left(\mathrm{dd}, J_{\mathrm{CF}}=245.8,13.1 \mathrm{~Hz}\right), 150.4\left(\mathrm{~d}, J_{\mathrm{CF}}=16.8 \mathrm{~Hz}\right), 145.5$, $142.6,138.4,136.4,130.2,128.7,128.5\left(\mathrm{~d}, J_{\mathrm{CF}}=15.9 \mathrm{~Hz}\right)$, $126.2,121.3,113.6\left(\mathrm{dd}, J_{\mathrm{CF}}=20.8,4.7 \mathrm{~Hz}\right), 102.7\left(\mathrm{t}, J_{\mathrm{CF}}=\right.$ $25.2 \mathrm{~Hz}$ ). HRMS (70 eV): calcd for $\mathrm{C}_{15} \mathrm{H}_{9} \mathrm{~F}_{2} \mathrm{~N} 241.0703$, found 241.0696. Anal. Calcd for $\mathrm{C}_{15} \mathrm{H}_{9} \mathrm{~F}_{2} \mathrm{~N}$ : C, 74.68; H, 3.76; F, 15.75; N, 5.81. Found: C, 74.65; H, 3.77; F, 15.75; N, 5.83.

8-(2,4-Difluorophenyl)quinoline (3d). This compound was prepared from 8-quinolyl trifluoromethanesulfonate (2) and 4,5-diflourophenylboronic acid according to the procedure described for 8-phenylquinoline (3a). ${ }^{1} \mathrm{H} \mathrm{NMR}\left(\mathrm{CDCl}_{3}, 600\right.$ $\mathrm{MHz}): \delta 8.91(\mathrm{dd}, J=4.2,1.8 \mathrm{~Hz}, 1 \mathrm{H}), 8.17(\mathrm{dd}, J=9.3,1.8$ $\mathrm{Hz}, 1 \mathrm{H}), 7.85$ (dd, $J=8.1,1.8 \mathrm{~Hz}, 1 \mathrm{H}), 7.68(\mathrm{~d}, J=7.2 \mathrm{~Hz}$, $1 \mathrm{H}), 7.59(\mathrm{t}, J=7.5 \mathrm{~Hz}, 1 \mathrm{H}), 7.49-7.45(\mathrm{~m}, 1 \mathrm{H}), 7.39(\mathrm{dd}, J=$ 8.4, 4.0.2 Hz, $1 \mathrm{H}), 7.00-6.95(\mathrm{~m}, 2 \mathrm{H}) .{ }^{13} \mathrm{C} \mathrm{NMR}\left(\mathrm{CDCl}_{3}, 150\right.$ $\mathrm{MHz}$ ) [ppm]: $\delta 162.6\left(\mathrm{dd}, J_{\mathrm{CF}}=247.1,11.7 \mathrm{~Hz}\right), 160.2(\mathrm{dd}$, $\left.J_{\mathrm{CF}}=248.1,11.9 \mathrm{~Hz}\right), 150.3,146.1,136.2,134.5,133.1(\mathrm{dd}$, $\left.J_{\mathrm{CF}}=8.6,5.0 \mathrm{~Hz}\right), 131.0,128.4,128.2\left(\mathrm{~d}, J_{\mathrm{CF}}=29.3 \mathrm{~Hz}\right), 125.9$ $\left(\mathrm{d}, J_{\mathrm{CF}}=24.3 \mathrm{~Hz}\right), 121.1,110.9\left(\mathrm{~d}, J_{\mathrm{CF}}=21.0 \mathrm{~Hz}\right), 103.9(\mathrm{t}$, $\left.J_{\mathrm{CF}}=25.8 \mathrm{~Hz}\right)$. HRMS $(70 \mathrm{eV})$ : calcd for $\mathrm{C}_{15} \mathrm{H}_{9} \mathrm{~F}_{2} \mathrm{~N} 241.0703$, found 241.0698. Anal. Calcd for $\mathrm{C}_{15} \mathrm{H}_{9} \mathrm{~F}_{2} \mathrm{~N}$ : C, 74.68; $\mathrm{H}, 3.76$; N, 5.81. Found: C, 74.66; H, 3.76; N, 5.80.

Ir[8-(Phenyl)quinoline $]_{2}$ (acac) (4a). To a mixed solvent (2-ethoxyethanol:/ $\mathrm{H}_{2} \mathrm{O}, 3: 1,60 \mathrm{~mL}$ ) of 8-phenylquinoline (3a) $(1.41 \mathrm{~g}, 6.85 \mathrm{mmol})$ was added $\mathrm{IrCl}_{3} \cdot 3 \mathrm{H}_{2} \mathrm{O}(1.18 \mathrm{~g}, 3.34 \mathrm{mmol})$, and the reaction mixture was heated to $120^{\circ} \mathrm{C}$ for $24 \mathrm{~h}$. The resulting solution was concentrated at $55^{\circ} \mathrm{C}$, the precipitates were filtered, and the solid was collected and washed with 100 $\mathrm{mL}$ of water, $50 \mathrm{~mL}$ of hexane, and $50 \mathrm{~mL}$ of ethyl ether. The mass of this dark brownish solid was $2.02 \mathrm{~g}(95 \%)$. To a 2-ethoxyethanol (15 mL) solution of this solid (2.02 g, 1.59 mmol) were added acetyl acetone $(0.39 \mathrm{~g}, 3.97 \mathrm{mmol})$ and sodium carbonate $(0.37 \mathrm{~g}, 3.49 \mathrm{mmol})$, and the reaction mixture was heated to $120{ }^{\circ} \mathrm{C}$ for $12 \mathrm{~h}$. After cooling to room temperature, a dark brownish precipitate was filtered off and washed 
with $200 \mathrm{~mL}$ of water, $100 \mathrm{~mL}$ of hexane, and $100 \mathrm{~mL}$ of ether. The crude product was chromatographed on a silica column $\left(\mathrm{CH}_{2} \mathrm{Cl}_{2} /\right.$ hexane, 1:6, $\left.R_{f}=0.5\right)$ to yield the pure $(C \wedge N)_{2} \operatorname{Ir}(\mathrm{acac})$ $4 \mathbf{a}(0.69 \mathrm{~g}, 32 \%)$. IR (Nujol): $2974(\mathrm{~m}), 2923(\mathrm{~m}), 2865(\mathrm{~m}), 2853-$ (m), 1572(s), 1541(s), 1393(s), 1352(s), 1180(s). ${ }^{1} \mathrm{H}$ NMR $\left(\mathrm{CDCl}_{3}, 600 \mathrm{MHz}\right): \delta 8.55(\mathrm{~d}, J=6.9 \mathrm{~Hz}, 2 \mathrm{H}), 8.34(\mathrm{~d}, J=8.9$ $\mathrm{Hz}, 2 \mathrm{H}), 8.08(\mathrm{~d}, J=9.7 \mathrm{~Hz}, 2 \mathrm{H}), 7.69(\mathrm{~d}, J=9.2 \mathrm{~Hz}, 2 \mathrm{H})$, $7.64-7.62(\mathrm{~m}, 4 \mathrm{H}), 7.05(\mathrm{t}, J=8.2 \mathrm{~Hz}, 2 \mathrm{H}), 6.95(\mathrm{~d}, J=8.0$ $\mathrm{Hz}, 2 \mathrm{H}), 6.70-6.65(\mathrm{~m}, 4 \mathrm{H}) 4.24(\mathrm{~s}, 1 \mathrm{H}), 1.07(\mathrm{~s}, 6 \mathrm{H}) .{ }^{13} \mathrm{C} \mathrm{NMR}$ $\left(\mathrm{CDCl}_{3}, 150 \mathrm{MHz}\right): \delta 184.4,154.3,145.0,142.6,142.3,141.7$, $137.8,136.5,128.7,127.7,126.6,126.6,125.4,122.7,120.4$, 99.1, 27.3. HRMS (70 eV): calcd for $\mathrm{C}_{35} \mathrm{H}_{23} \mathrm{~F}_{4} \mathrm{IrN}_{2} \mathrm{O}_{2} 700.1702$, found 700.1722. Anal. Calcd for $\mathrm{C}_{35} \mathrm{H}_{23} \mathrm{~F}_{4} \mathrm{IrN}_{2} \mathrm{O}_{2}$ : C, 60.07; $\mathrm{H}$, 3.89 ; N, 4.00. Found: C, $60.12 ; \mathrm{H}, 3.82 ; \mathrm{N}, 4.03$.

$\operatorname{Ir}[8-(4-f l u o r o p h e n y l) q u i n o l i n e]_{2}$ (acac) (4b). This compound was prepared from 8-(4-fluorophenyl)quinoline (3b), acetyl acetone, and $\mathrm{IrCl}_{3} \cdot 3 \mathrm{H}_{2} \mathrm{O}$ according to the procedure described for $\operatorname{Ir}(8 \text {-phenylquinoline })_{2}$ (acac) (4a). IR (Nujol): $2972(\mathrm{~m}), 2922(\mathrm{~m}), 2865(\mathrm{~m}), 2851(\mathrm{~m}), 1579(\mathrm{~s}), 1543(\mathrm{~s}), 1392-$ (s), 1351(s), 1177(s). ${ }^{1} \mathrm{H} \mathrm{NMR}\left(\mathrm{CDCl}_{3}, 500 \mathrm{MHz}\right): \delta 8.52(\mathrm{~d}, J$ $=5.5 \mathrm{~Hz}, 2 \mathrm{H}), 8.25(\mathrm{dd}, J=6.5,2.0 \mathrm{~Hz}, 2 \mathrm{H}), 8.12(\mathrm{dd}, J=$ 8.0, $1.5 \mathrm{~Hz}, 2 \mathrm{H}), 7.65-7.61(\mathrm{~m}, 6 \mathrm{H}), 7.00(\mathrm{dd}, J=8.0,5.1 \mathrm{~Hz}$, $2 \mathrm{H}), 6.74(\mathrm{dt}, J=8.5,3.2 \mathrm{~Hz}, 2 \mathrm{H}), 6.29(\mathrm{dd}, J=10.5,2.0 \mathrm{~Hz}$, $2 \mathrm{H}), 4.24(\mathrm{~s}, 1 \mathrm{H}), 1.07(\mathrm{~s}, 6 \mathrm{H}) .{ }^{13} \mathrm{C} \mathrm{NMR}\left(\mathrm{CDCl}_{3}, 125 \mathrm{MHz}\right): \delta$ $184.6,161.0\left(\mathrm{~d}, J_{\mathrm{CF}}=247.3 \mathrm{~Hz}\right), 154.3,144.7,143.7,141.6$, $137.1,134.2,128.7,128.0\left(\mathrm{~d}, J_{\mathrm{CF}}=8.9 \mathrm{~Hz}\right), 127.8\left(\mathrm{~d}, J_{\mathrm{CF}}=\right.$ $4.4 \mathrm{~Hz}), 127.1\left(\mathrm{~d}, J_{\mathrm{CF}}=15.5 \mathrm{~Hz}\right), 125.5,120.5,110.0\left(\mathrm{~d}, J_{\mathrm{CF}}=\right.$ $22.3 \mathrm{~Hz}$ ), 99.3, 27.3. HRMS (70 eV): calcd for $\mathrm{C}_{35} \mathrm{H}_{25} \mathrm{~F}_{2} \mathrm{IrN}_{2} \mathrm{O}_{2}$ 736.1513, found 736.1511. Anal. Calcd for $\mathrm{C}_{35} \mathrm{H}_{25} \mathrm{~F}_{2} \mathrm{IrN}_{2} \mathrm{O}_{2}$ : C, 57.13; H, 3.42; N, 3.81. Found: C, 57.03; H, 3.40; N, 3.79.

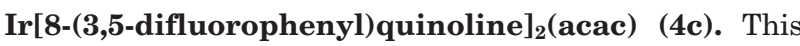
compound was prepared from 8-(3,5-difluorophenyl)quinoline (3c), acetyl acetone, and $\mathrm{IrCl}_{3} \cdot 3 \mathrm{H}_{2} \mathrm{O}$ according to the procedure described for $\operatorname{Ir}\left[8\right.$-(phenyl)quinoline ${ }_{2}$ (acac) (4a). IR (Nujol): $2981(\mathrm{~m}), 2933(\mathrm{~m}), 2861(\mathrm{~m}), 2859(\mathrm{~m}), 1570(\mathrm{~s}), 1544(\mathrm{~s}), 1390$ (s), 1356(s), 1182(s). ${ }^{1} \mathrm{H}$ NMR $\left(\mathrm{CDCl}_{3}, 600 \mathrm{MHz}\right): \delta 8.54(\mathrm{dd}$, $J=5.4,1.4 \mathrm{~Hz}, 2 \mathrm{H}), 8.29(\mathrm{dd}, J=7.4,1.3 \mathrm{~Hz}, 2 \mathrm{H}), 8.07(\mathrm{dd}$, $J=8.1,1.4 \mathrm{~Hz}, 2 \mathrm{H}), 7.69-7.62(\mathrm{~m}, 4 \mathrm{H}), 7.37(\mathrm{dd}, J=11.3$, $2.5 \mathrm{~Hz}, 2 \mathrm{H}), 6.98(\mathrm{dd}, J=8.1,5.3 \mathrm{~Hz}, 2 \mathrm{H}), 6.32(\mathrm{dt}, J=9.0$, $2.5 \mathrm{~Hz}, 2 \mathrm{H}), 4.23(\mathrm{~s}, 1 \mathrm{H}), 1.06(\mathrm{~s}, 6 \mathrm{H}) .{ }^{13} \mathrm{C} \mathrm{NMR}\left(\mathrm{CDCl}_{3}, 150\right.$ $\mathrm{MHz}): \delta 184.1,169.4\left(\mathrm{dd}, J_{\mathrm{CF}}=234.7,11.3 \mathrm{~Hz}\right), 160.8(\mathrm{dd}$, $\left.J_{\mathrm{CF}}=234.9,13.5 \mathrm{~Hz}\right), 152.8,144.5,141.5\left(\mathrm{~d}, J_{\mathrm{CF}}=7.7 \mathrm{~Hz}\right)$, $141.4,136.7,128.7,128.4,127.5,126.6,120.4,115.8\left(\mathrm{~d}, J_{\mathrm{CF}}=\right.$ $34.8 \mathrm{~Hz}), 110.0\left(\mathrm{~d}, J_{\mathrm{CF}}=22.3 \mathrm{~Hz}\right), 109.9\left(\mathrm{~d}, J_{\mathrm{CF}}=20.1 \mathrm{~Hz}\right)$, $101.6\left(\mathrm{dd}, J_{\mathrm{CF}}=33.3,23.7 \mathrm{~Hz}\right), 99.4,27.1$. HRMS $(70 \mathrm{eV})$ : calcd for $\mathrm{C}_{35} \mathrm{H}_{23} \mathrm{~F}_{4} \mathrm{IrN}_{2} \mathrm{O}_{2} 772.1325$, found 772.1328. Anal. Calcd for $\mathrm{C}_{35} \mathrm{H}_{23} \mathrm{~F}_{4} \mathrm{IrN}_{2} \mathrm{O}_{2}$ : C, 54.47; H, 3.00; N, 3.63. Found: C, 54.40; $\mathrm{H}, 3.10 ; \mathrm{N}, 3.69$.

$\operatorname{Ir}[8-(3,5-d i f l u o r o p h e n y l) q u i n o l i n e]_{2}$ (acac) (4d). This compound was prepared from 8-(3,5-difluorophenyl)quinoline $(\mathbf{3 d})$, acetyl acetone, and $\mathrm{IrCl}_{3} \cdot 3 \mathrm{H}_{2} \mathrm{O}$ according to the procedure described for $\operatorname{Ir}[8 \text {-(phenyl)quinoline }]_{2}$ (acac) (4a). IR (Nujol): $2983(\mathrm{~m}), 2932(\mathrm{~m}), 2860(\mathrm{~m}), 2855(\mathrm{~m}), 1572(\mathrm{~s}), 1545(\mathrm{~s}), 1393-$ (s), 1352(s), 1184(s). ${ }^{1} \mathrm{H} \mathrm{NMR}\left(\mathrm{CDCl}_{3}, 600 \mathrm{MHz}\right): \delta 8.50(\mathrm{dd}$, $J=5.3,1.4 \mathrm{~Hz}, 2 \mathrm{H}), 8.35(\mathrm{dt}, J=6.7,1.4 \mathrm{~Hz}, 2 \mathrm{H}), 8.14(\mathrm{dd}$, $J=8.1,1.4 \mathrm{~Hz}, 2 \mathrm{H}), 7.68-7.62(\mathrm{~m}, 4 \mathrm{H}), 7.04(\mathrm{dd}, J=8.1,5.3$ $\mathrm{Hz}, 2 \mathrm{H}), 6.51(\mathrm{dt}, J=10.9,2.6 \mathrm{~Hz}, 2 \mathrm{H}), 6.12(\mathrm{dd}, J=9.5,2.6$ $\mathrm{Hz}, 2 \mathrm{H}), 4.18(\mathrm{~s}, 1 \mathrm{H}), 1.02(\mathrm{~s}, 6 \mathrm{H}) .{ }^{13} \mathrm{C} \mathrm{NMR}\left(\mathrm{CDCl}_{3}, 150\right.$ $\mathrm{MHz}): \delta 184.4,161.1\left(\mathrm{dd}, J_{\mathrm{CF}}=249.7,13.1 \mathrm{~Hz}\right), 158.1(\mathrm{dd}$, $\left.J_{\mathrm{CF}}=253.7,12.0 \mathrm{~Hz}\right), 154.2,146.2,145.4,137.3,135.1,132.2$ $\left(\mathrm{d}, J_{\mathrm{CF}}=15.0 \mathrm{~Hz}\right), 128.6,127.1,125.7,123.3\left(\mathrm{~d}, J_{\mathrm{CF}}=15.6\right.$ $\mathrm{Hz}), 120.4,99.2,98.7\left(\mathrm{t}, J_{\mathrm{CF}}=28.1 \mathrm{~Hz}\right), 27.0$. HRMS $(70 \mathrm{eV})$ : calcd for $\mathrm{C}_{35} \mathrm{H}_{23} \mathrm{~F}_{4} \mathrm{IrN}_{2} \mathrm{O}_{2}$ 772.1325, found 772.1311. Anal. Calcd for $\mathrm{C}_{35} \mathrm{H}_{23} \mathrm{~F}_{4} \mathrm{IrN}_{2} \mathrm{O}_{2}$ : C, 54.47; H, 3.00; N, 3.63. Found: C, 54.39; H, 3.05; N, 3.72.

Measurement of Lifetime, Quantum Yields, and Photoelectron Spectroscopy. Steady state absorption and emission spectra were recorded by a Hitachi (U-3310) spectrophotometer and an Edinburgh (FS920) fluorimeter, respectively. Both wavelength-dependent excitation and emission response of the fluorimeter have been calibrated. A configuration of front-face excitation was used to measure the emission of the solid sample, in which the cell was made by assembling two edge-polished quartz plates with various Teflon spacers. A combination of appropriate filters was used to avoid the interference from the scattering light. To determine the photoluminescence quantum yield in solution, samples were degassed by three freeze-pump-thaw cycles under vigorous stirring conditions. 4-(Dicyanomethylene)-2-methyl-6-( $p$-dimethylaminostyryl)- $4 H$-pyran (DCM, $\lambda_{\mathrm{em}}=620 \mathrm{~nm}$, Exciton, Inc.) in methanol was used as a reference, assuming a quantum yield of 0.43 with a $460 \mathrm{~nm}$ excitation. ${ }^{13}$

Lifetime studies were performed by an Edinburgh FL 900 photon-counting system with a hydrogen-filled/or a nitrogen lamp as the excitation source. Data were analyzed using the nonlinear least squares procedure in combination with an iterative convolution method. Single-exponential emission decay was obtained for all studied compounds.

Theoretic Calculation. Calculations on the electronic ground states of complex $\mathbf{4 b}$ were carried out using B3LYP density functional theory. ${ }^{14,15}$ Double- $\zeta$ quality basis sets were employed for the ligands (6-31G*) and the Ir atom (LANL2DZ). A relativistic effective core potential on $\operatorname{Ir}^{16}$ replaced the inner core electrons leaving the outer core $\left[(5 s)^{2}(5 p)^{6}\right]$ electrons and the $(5 \mathrm{~d})^{6}$ valence electrons of IIIII. The ground state geometry was adapted from the truncated X-ray data without further optimization. At the geometry, a time-dependent DFT (TDDFT) calculation ${ }^{17}$ using the B3LYP functional was performed. Typically, the lowest 10 triplet and 10 singlet roots of the nonhermitian eigenvalue equations were obtained to determine the vertical excitation energies. Oscillator strengths were deduced from the dipole transition matrix elements (for singlet states only). The ground state B3LYP and excited state TDDFT calculations were carried out using Gaussian98. ${ }^{18}$

OLED Fabrication and Measurements. Prepatterned ITO substrates with an effective individual device area of 3.14 $\mathrm{mm}$ were cleaned by sonication in a detergent solution for 3 min and then washed with a large amount of doubly distilled water. Further sonication in ethanol for 3 min was done before blowing dry with a stream of nitrogen. The ITO substrates were then treated with $\mathrm{O}_{2}$ plasma for 1 min before loaded into the vacuum chamber. The organic layers were deposited thermally at a rate of $0.1-0.3 \mathrm{~nm} / \mathrm{s}$ under a pressure of $\sim 5 \times$ $10^{-6}$ Torr in an Ulvac Cryogenic deposition system. Typical devices were constructed with $40 \mathrm{~nm}$ of NPB as the holetransporting layer (HTL), $30 \mathrm{~nm}$ CBP doped with iridium complex as the emission layer, and $30 \mathrm{~nm}$ of $\mathrm{Alq}_{3}$ as the ETL. An alloy of magnesium and silver (ca. 10:1, $50 \mathrm{~nm}$ ) was deposited as the cathode, which was capped with $100 \mathrm{~nm}$ of

(13) Drake, J. M.; Lesiecki, M. L.; Camaioni, D. M. Chem. Phys. Lett. 1985, 113,530

(14) Lee, C.; Yang, W. Parr, R. G. Phys, Rev. B 1988, 37, 785.

(15) Becke, A. D. J. Chem. Phys. 1993, 98, 5648.

(16) Hay, P. J.; Wadt, W. R. J. Chem. Phys. 1985, 82, 299-310.

(17) (a) Jamorski, C.; Casida, M. E.; Salahub, D. R. J. Chem. Phys. 1996, 104, 5134. (b) Petersilka, M.; Grossmann, U. J.; Gross, E. K. U. Phys. Rev. Lett. 1996, 76, 1212. (c) Bauernschmitt, R.; Ahlrichs, R.; Hennrich, F. H.; Kappes, M. M. J. Am. Chem. Soc. 1998, 120, 5052 (d) Casida, M. E. J. Chem. Phys. 1998, 108, 4439. (e) Stratmann, R. E.; Scuseria, G. E.; Frisch, M. J. J. Chem. Phys. 1998, 109, 8218.

(18) Frisch, M. J.; Trucks, G. W.; Schlegel, H. B.; Scuseria, G. E.; Robb, M. A.; Cheeseman, J. R.; Zakrzewski, V. G.; Montgomery, J. A. Jr.; Stratmann, R. E.; Burant, J. C.; Dapprich, S.; Millam, J. M. Daniels, A. D.; Kudin, K. N.; Strain, M. C.; Farkas, O.; Tomasi, J.; Barone, V.; Cossi, M.; Cammi, R.; Mennucci, B.; Pomelli, C.; Adamo, C.; Clifford, S.; Ochterski, J.; Petersson, G. A.; Ayala, P. Y.; Cui, Q.; Morokuma, K.; Malick, D. K.; Rabuck, A. D.; Raghavachari, K. Foresman, J. B.; Cioslowski, J.; Ortiz, J. V.; Stefanov, B. B.; Liu, G.; Liashenko, A.; Piskorz, P.; Komaromi, I.; Gomperts, R.; Martin, R. L.; Fox, D. J.; Keith, T.; Al-Laham, M. A.; Peng, C. Y.; Nanayakkara, A.; Gonzalez, C.; Challacombe, M.; Gill, P. M. W.; Johnson, B. G.; Chen, W.; Wong, M. W.; Andres, J. L.; Head-Gordon, M.; Replogle, E. S.; Pople, J. A. Gaussian 98, revision A.9; Gaussian, Inc.: Pittsburgh, PA, 1998. 
silver. The current-voltage-luminance was measured in ambient with a Keithley 2400 source meter and a Newport $1835 \mathrm{C}$ optical meter equipped with $818 \mathrm{ST}$ silicon photodiode.

The HOMO energy level was measured with a photoelectron spectrometer (model AC-2, Riken Keiki) on an evaporated thin film of the organic compound.

Acknowledgment. The authors wish to thank the National Science Council, Taiwan, for supporting this work.
Supporting Information Available: Crystallographic information files for $\mathbf{4 b}$; table of crystal data and structure refinement for $\mathbf{4 b}$ (Table S1), table of atomic coordinates and equivalent isotropic displacement parameters for $\mathbf{4 b}$ (Table S2), table of bond lengths and angles for $\mathbf{4 b}$ (Table S3), table of anisotropic displacement parameters for $\mathbf{4 b}$ (Table S4), and table of hydrogen coordinates and isotropic displacement parameters for $\mathbf{4 b}$ (Table S5). These materials are available free of charge via the Internet at http://pubs.acs.org.

OM049192N 